\title{
WATER MANAGEMENT PROBLEMS AT THE BUKÓWKA DRINKING WATER RESERVOIR'S CROSS-BORDER BASIN AREA IN TERMS OF ITS ESTABLISHED FUNCTIONS
}

\author{
Mirosław Wiatkowski', Czesława Rosik-Dulewska² \\ 1 Institute of Environmental Engineering, Wrocław University of Environmental and Life Sciences, Plac \\ Grunwaldzki 24, 50-363 Wrocław, Poland, e-mail: miroslaw.wiatkowski@up.wroc.pl \\ 2 Department of Land Protection, Opole University, Oleska Str. 22, 45-052 Opole, Poland, e-mail: czeslawa. \\ rosik-dulewska@ipis.zabrze.pl
}

Received: 2014.12.27

Accepted: 2015.02.04

Published: 2015.04.01

\begin{abstract}
The paper covers the analysis of water management problems in the cross-border reservoir basin of Bukówka, located at the Bóbr river, at 271+540 km of its course, below the Czech-Polish border, in Dolnośląskie Voivodeship. The problems of water management in the context of the reservoir's functions have been analyzed; these are: flood control, the provision of water during low water level periods for the Water Treatment Plant in Marciszów, the provision of drinking water for the city of Wałbrzych as well as the provision of proper flow in the Bóbr river bed downstream from the reservoir. Due to its localization right below the border with the Czech Republic, the reservoir is exposed to a number of problems. The study has found that the main problems of water management in the basin area included unsatisfactory state of water and wastewater management in the basin, unsatisfactory state of the surface water quality in the basin area of the reservoir, poor condition of streams and drainage ditches, improper arrangement of arable lands and large downslopes and a lack of monitoring stations on tributaries of the reservoir. It has been found that the hydrochemical conditions in the Bukówka reservoir's section are unfavorable for it. From the eutrophication point of view, the water flowing into the tank is characterized by a large content of nutrients, especially nitrates, phosphates and $\mathrm{BOD}_{5}$. In order to counteract eutrophication it is necessary to lower the concentration of nutrients in the water flowing into the tank. One of the basic ways to do so is to restore the water and wastewater management in the reservoir's basin. Studies in the Bukówka reservoir provide important information concerning the state of the purity of the water supplying the reservoir. In order to obtain accurate information on the state of purity, a monitoring of hydrological and water quality should be continued. The studies are a part of the strategy of protection of the quality of transboundary waters, proposed in the Convention on the Protection and Use of Transboundary Watercourses and International Lakes of 1992.
\end{abstract}

Keywords: drinking water reservoir, water management, cross-border basin area, water quality.

\section{INTRODUCTION}

Proper water management in retention reservoirs' basins is enormously important due to the fact that these reservoirs are places of accumulation of nutrients and various pollutants carried by a river. As a result of these processes the quality of water may deteriorate or its eutrophication and silting may occur [Balcerzak 2006, Czamara at al. 2008, Pawełek at al. 2014, Pütz, Paul 2008, Wiatkowski 2011]. These phenomena may often hinder the fulfillment of a reservoir's functions as well as reduce water utility and aesthetic values of reservoirs themselves [Kanownik at al. 2011, Wiatkowski et al. 2010]. Because of that, a reservoir's functions may not be fulfilled [Pütz, 
Benndorf 1981; Wiatkowski, Paul 2009]. It is important to maintain water management of basins of multi-purpose reservoirs, including those containing drinking water, located at border areas, which due to their numerous functions are particularly vulnerable to pollutants from their basins. One of such multi-purpose reservoirs existing on the Odra is the Bukówka reservoir. It is located on the Bóbr river at 271+540 km, in Lower Silesia. Its basic functions are flood control, water provision during low water periods for the Water Treatment Plant in Marciszów and provision of drinking water for the city of Wałbrzych, although this last function is not fulfilled and the water from the reservoir is used for consumption only for the citizens of Bukówka village, and in order to ensure the proper flow into the riverbed of the Bóbr river, downstream from the reservoir [Operat 2007]. Due to the fact that the Bukówka reservoir is located just below the border with the Czech Republic, it is exposed to a number of problems, among which the main is the deterioration of the water quality in the reservoir. Due to its crossborder location and economic importance, it is crucial to monitor the reservoir's water quality as well as the water quality of its tributaries. In such a situation, the regional water administration is supposed to organize and stimulate the protection and rational use of water, under the integrated water policy of the EC. These issues are particularly important in case of transboundary waters, which according to the Art. 1 of the Convention [Konwencja 1992] are any surface or ground waters which mark and cross a border between two or more countries or are located on such borders. Tasks for such type of waters are presented in the Directive 97/11/EC [Dyrektywa 1997]. It obliges parties managing transboundary waters to analyze the state of the environment in these areas and to carry out strategic environmental impact assessments, from the plans and policies to individual investments. The Directive 97/11/EC recognizes the need to implement the following postulates:

- The obligation to remove any environmental damage at its source as well as the "polluter pays" principle,

- The achievement of good water status as a strategic goal, postulating a reduction of dangerous substances emission into the water at the same time,

- Performance of analysis of the water status in particular basins, evaluation of anthropogenic impacts including water economy (it is recom- mended to implement water service charges in the amount covering water management costs, including expenditures on water protection and restoration of ecological of a water-related environment).

Therefore, it is very important to characterize thoroughly selected water management problems in the basin area of a cross-border retention reservoir, to indicate results of water management interactions and to present proposals of how to improve this condition. Because transboundary impact means any impact resulting in significant adverse effects on the environment in the area under the jurisdiction of one party, being a result of changes in transboundary waters caused by human activity, in which the physical beginning is situated entirely or partly in the area under the jurisdiction of another party; such effects on the environment include, among others, impact on water and other physical structures or interactions between these factors [Konwencja 1992].

The purpose of this article is to present some water management problems in the Bukówka reservoir basin located on the Bóbr river, below the Polish-Czech border. Particular attention was paid to the water quality of the Bukówka reservoir tributaries.

\section{METHODOLOGY}

The study included an inventory of the basin between January 2006 and December 2007 concerning the operation of the Bukówka drinking water reservoir on the Bóbr river. Particular attention was paid to the assessment of the Bóbr river water quality, the Bukówka reservoir tributary. In addition, the results of the water quality of four tributaries were presented: Opawa, Złotna, Bachorzyna and Paprotki. In order to create water quality characteristics, the results of our own research were used (from the period of November 2006-December 2007), as well as the results from the Regional Inspectorate for Environmental Protection in Wrocław (period 1993-2005) [Raport 2005] and from the study "Vodohospodářské bilance for 2011, období 2006-2011 and výhledu k 2021" (period 2009-2011) [Havranek et al. 2011]. The following indicators of water quality were analyzed: $\mathrm{N}_{\text {tot }}, \mathrm{NO}_{3}^{-}, \mathrm{NO}_{2}^{-}, \mathrm{NH}_{4}^{+}, \mathrm{PO}_{4}^{3-}, \mathrm{BOD}_{5}$, water $\mathrm{pH}$, electrolytic conductivity, the number of fecal coliform bacteria, water temperature, and total suspended solids. 
The quality of the reservoir's tributaries was assessed in accordance with the applicable Decree on the classification of surface water bodies [Rozporządzenie 2011]; an assessment of water eutrophication was presented on the basis of the Decree of the Minister of the Environment of 2002 on the criteria for indicating waters vulnerable to pollution by nitrogen compounds from agriculture [Rozporządzenie 2002]. The basin and the reservoir exploitation were analyzed, as well as water management at the reservoir. Particular attention was paid to the quality of the water supplying the reservoir, the water of the reservoir itself, as well as the water outflow from it; proposals of actions to limit the impact of improper water management were presented.

\section{THE OBJECT CHARACTERISTICS}

The Bukówka water reservoir is located on the Bóbr river at 271+540 km (left-hand tributary of the Odra river), in the Lubawka municipality, Kamienna district. The Bukówka reservoir is one of the highest above-sea-level dam reservoirs in Poland. Its main components are the reservoir's bowl (Figure 1a, b): an earth dam with drain devices. The central dam is located between two mountains: Zameczek and Zadzierna (Figure 1c). Moreover, the reservoir consists of bottom release, surface spillway, intake of tap water for Wałbrzych Water and Sewage Enterprise, which is currently not in operation, hydroelectric power plant and side dam Miszkowice (Figure 1d, e). Almost the

a)

b)

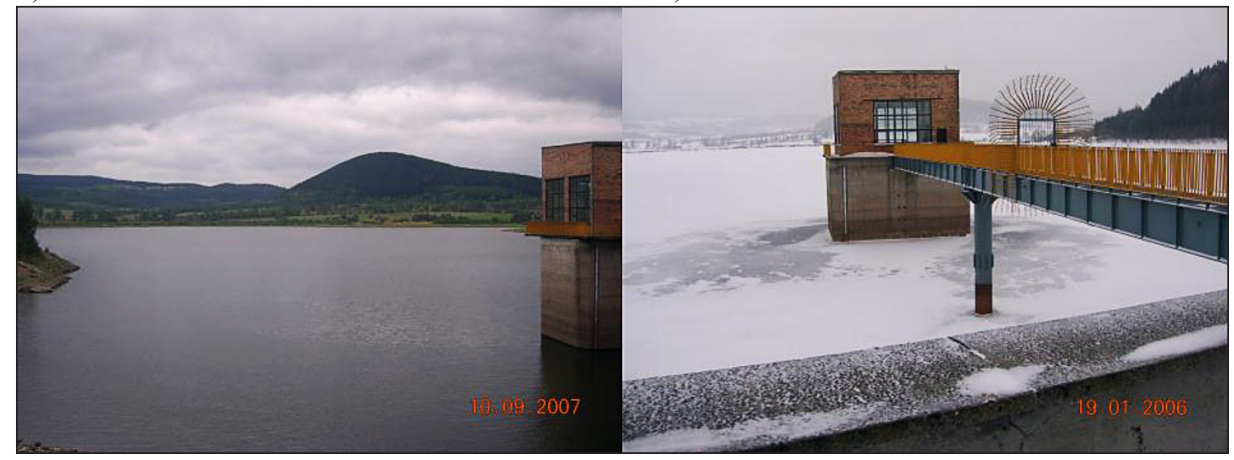

c)

d)

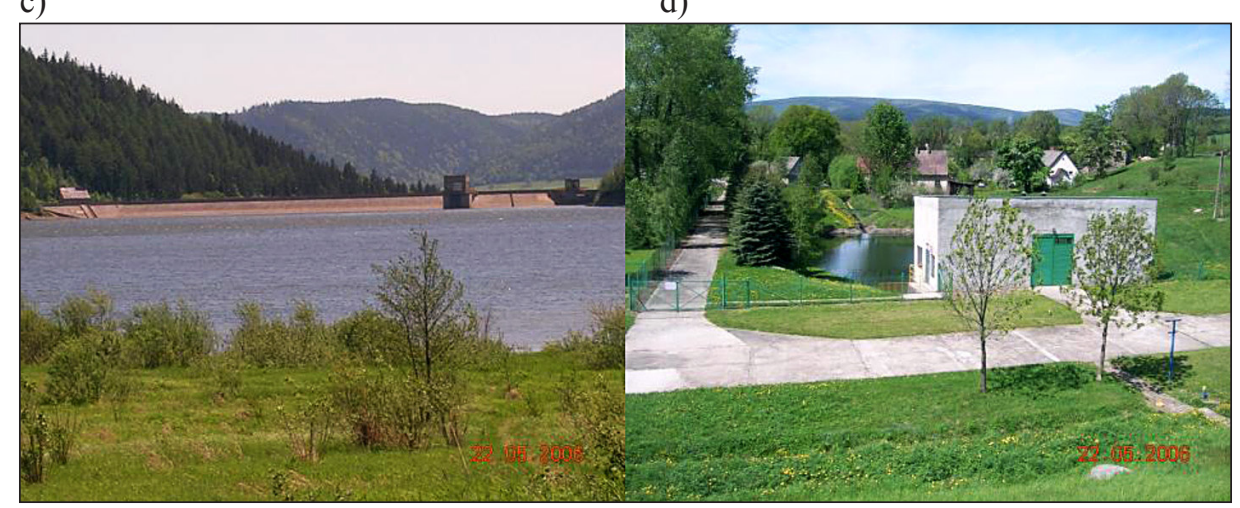

e)

f)

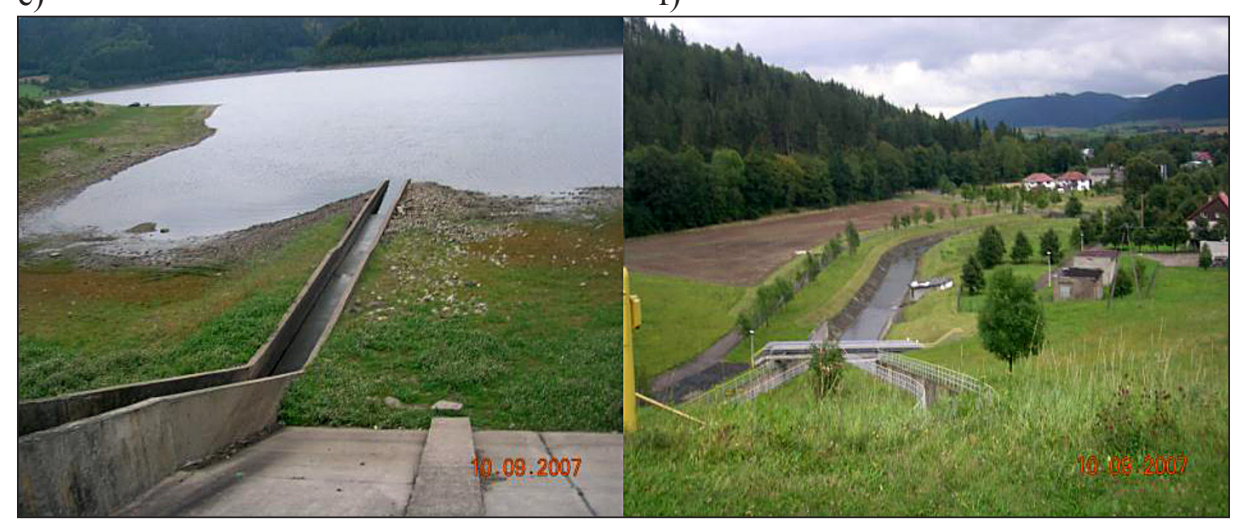

Figure 1. The Bukówka reservoir's bowl (a, b), ground dam (c), the Miszkowice reservoir (d), the side dam Miszkowice and the polder ourflow (s), The Bóbr riverbed from the Bukówka reservoir (f) 
entire reservoir is limited by natural banks, except for the front and side dams (Figure 1f). The side dam is located in the Miszkowice village area in the western part of the reservoir. The function of the side dam is to protect the Miszkowice village from the reservoir's backflow. Since Miszkowice polder is not capable of performing gravitational drainage, drainage pumping is done using three pumps. Water management in the polder is automated [Manual 2007]. The parameters of the tank: 12.01 million $\mathrm{m}^{3}$ and 167.0 ha at a normal level and 16.790 million $\mathrm{m}^{3}$ and 199.0 ha at maximum flood level [Operat 2007].

The outflow from the reservoir is done through bottom release and surface spillway (Figure 1f). On the wall of the bottom release a gauge patch is placed (Figure 1a, b), and also the reservoir is equipped with a limnigraph. An operator discharges water from a modern control room located in the tower of inflow and outflow (Figure $1 \mathrm{a}, \mathrm{b})$. The dam is also equipped with piezometers and a drainage trench located on the air side of the dam.

\section{RESULTS AND DISCUSSION}

\section{Exploitation of the basin and the reservoirs}

The area of the basin in the Bukówka reservoir dam section is $58.5 \mathrm{~km}^{2}$, of which the Bóbr river flows $4.6 \mathrm{~km}^{2}$ into Poland. The Bóbr river flows into the Czech Republic for about two kilo-

a)

b)

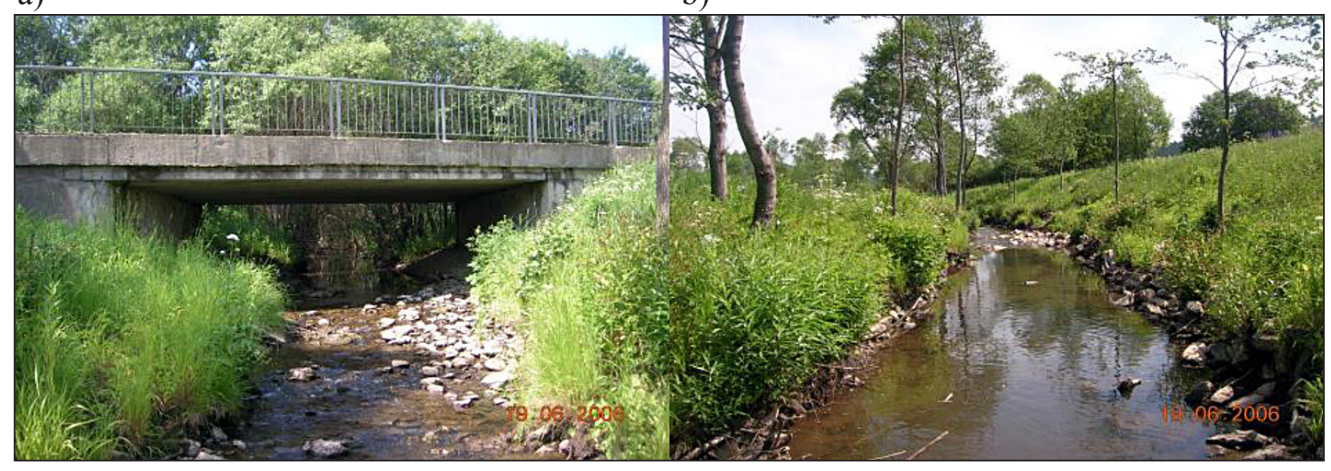

c)

d)

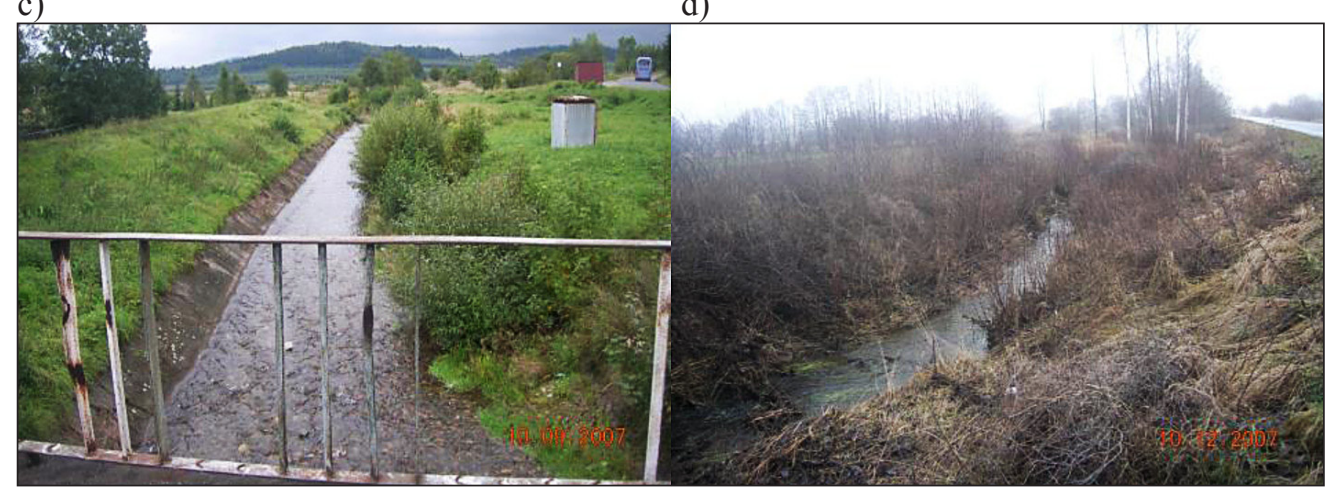

e)

f)

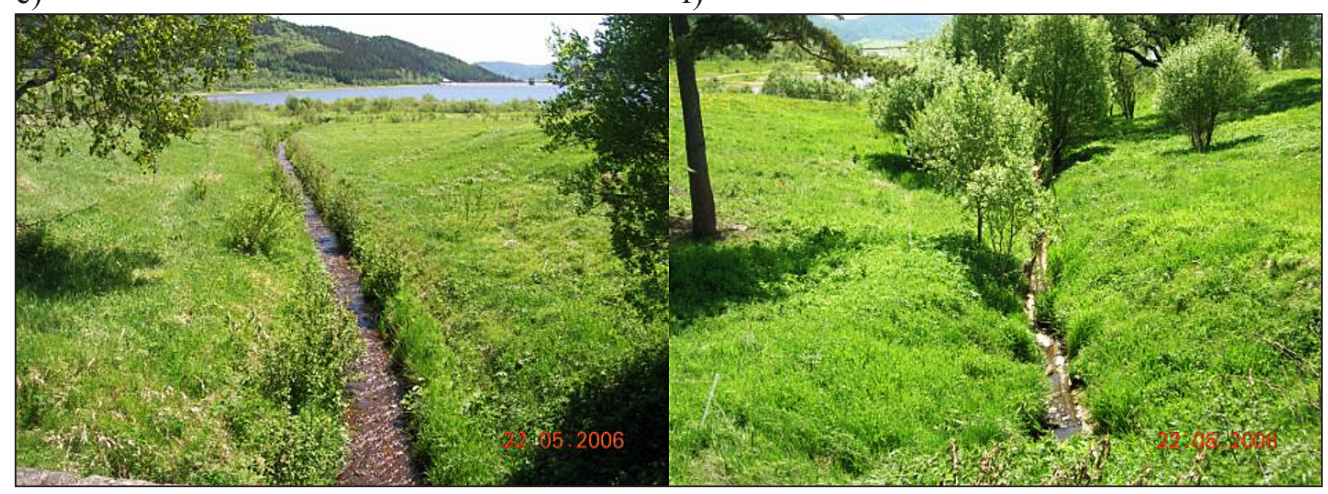

Figure 2. The Bukówka reservoir's tributaries: Bóbr riverbed (a, b), Złotna (c), Opawa (d), Bachorzyna (e), Paprotki (f) 
meters, then more than four kilometers in Poland, and flows into the Bukówka reservoir [Ocena 2007; Report 2005]. The longitudinal slope of the Bukówka reservoir's basin is approx. 8.8\%. The basin area is used for agriculture (approx. 50\%) and covered with woods (approx. 45\%). There is also a visible slope of the basin, mostly from west to east, and in the southern part of the basin from south west to north east [Operat 2007]. The Bukówka reservoir is a recipient of several watercourses (Figure 2): rivers Bóbr, Złotna, Opawa and Bachorzyna; it also receives waters from several drainage ditches: Paprotki and pumped water from the Miszkowice polder.

In the basin area of the reservoir are located villages: Miszkowice, Opawa, Jarkowice, Niedamirów and Paprotki. The average population in the basin area is approx. 25 persons $/ \mathrm{km}^{2}$. At the moment of the research on the basin area of the reservoir, there was no overall sewage system. The municipal sewage formed in the reservoir's basin was channeled mainly to the Złotna river, and Paprotki ditch, which are above the tank.

Agriculture, water and wastewater management in the reservoirs basins, both direct and indirect, are not without significance to the quality of water bodies. According to Pütz and Paul [2008] and Pütz and Benndorf [1981] a kind of reservoir basin, in case of which the issue of water management should be thoroughly considered, is a drinking water reservoir basin. In addition, in a case where slopes in the near basin area of the reservoir are large (in case of the Bukówka reservoir longitudinal north-east declines from Zadzierna mountain range from 10 to $60 \%$ and at the southern, Szczepanów side from 5-12\%), and along the slope there is agriculture (Figure 3a), with surface runoff waters and various pollutions, including fertilizing substances, get into a reservoir.

During the study period the Bukówka reservoir was also used by anglers. According to the rules any other possibility of recreational use of the reservoir during the study period was not allowed. However, as it was noted, the reservoir was used by the public for recreational purposes and bathing (Figure 3b, c, d). There is no doubt that the Bukówka reservoir due to its large area of various coastlines, perfectly blended into the surrounding mountains, is a recreational and landscape attraction. Therefore, attempts were made to obtain permission for recreational use of the reservoir. It is worth noting, however, that in this case it is necessary to perform the assessment of the possibilities of adapting it for recreational purposes. The most important is the tourism capacity, not only because of the perfect leisure condi- a)

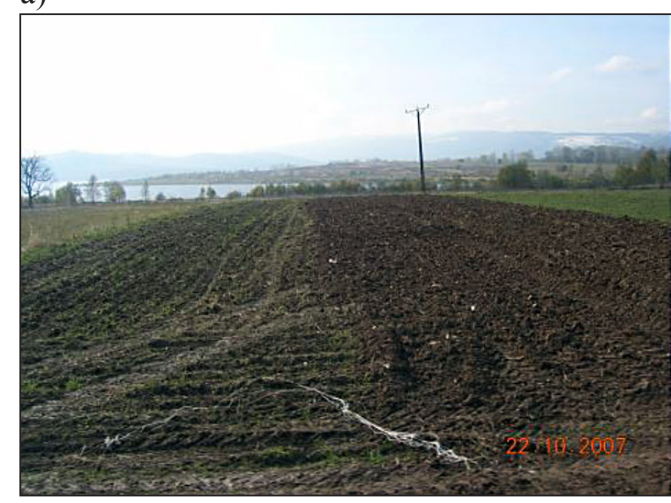

c)

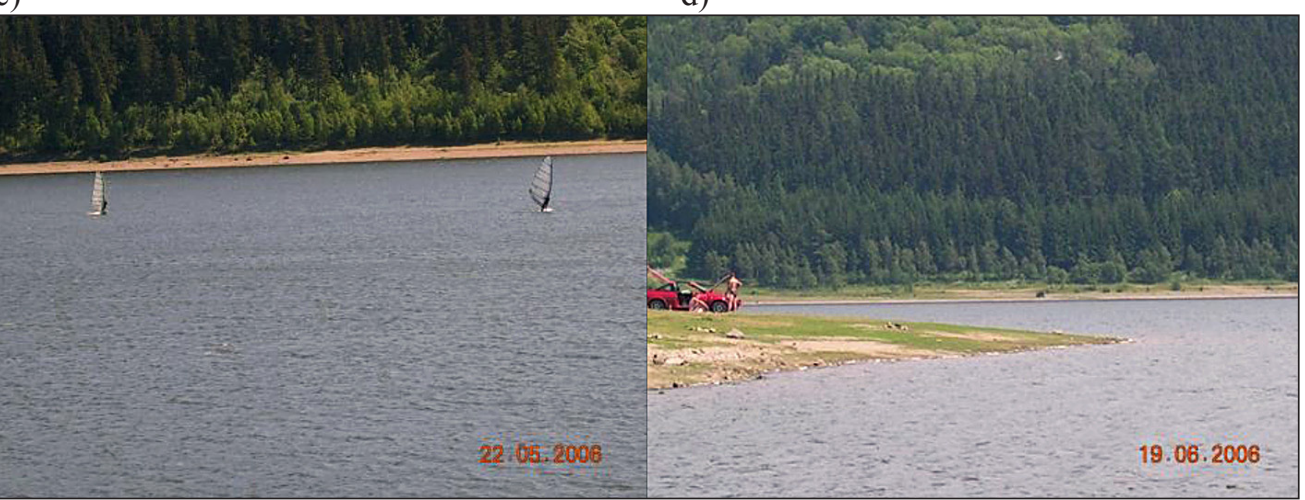

Figure 3. The usage of the Bukówka reservoir b)

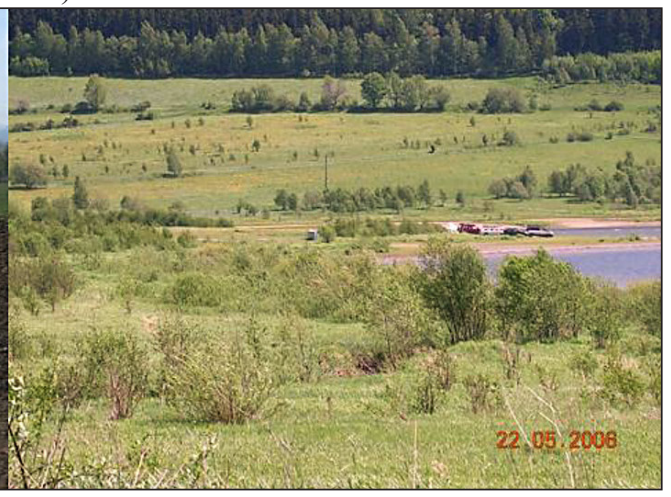

d) 
tions, but mostly due to the need to protect the tank from excessive tourism pressure and preservation of the principles of balanced development and protection. There is no doubt that in the present conditions of declining water resources such measures become necessary, though they must be related to the proper water and wastewater management in the reservoir's basin.

\section{Water management at the reservoir}

We may distinguish four periods of water management at the Bukówka reservoir. It is water management under normal operating conditions, the conditions of flood, drought and the period of ice phenomena. As is stated in the Manual of water management [Instrukcja, 2007], water management at the reservoir during the normal operating period is a management within the usable capacity, ranging between the minimum level of damming - 521.30 meters above sea level and the normal level of 534.30 meters above sea level. Water management in these circumstances should ensure drainage of the reservoir's proper flow downstream $\left(0.10 \mathrm{~m}^{3} \cdot \mathrm{s}^{-1}\right)$ and provide water to the intake in Marciszów $\left(0.56 \mathrm{~m}^{3} \cdot \mathrm{s}^{-1}\right)$. Outflow instruction is given once a day at $7.00 \mathrm{am}$ (also at other times when the situation requires a change in the size of an outflow). During the period of study on the reservoir as well as on its inlet the gauge patches were installed.

Flood conditions of the flood management at the Bukówka reservoir are managed when impoundment at the reservoir is equal or bigger than normally and when inflow to the reservoir is larger than the permitted $\mathrm{Q}_{\mathrm{doz}}$ flow of $8.00 \mathrm{~m}^{3} \cdot \mathrm{s}^{-1}$. The reservoir's flood management applies to the constant reserve management, i.e. the tank capacity between the normal (534.30 meters above sea level) and the maximum level of impoundments (536.30 meters above sea level). Moreover it applies to the forced flood reserve, i.e. the tank capacity between the maximum and the extraordinary levels of impoundments - 537.10 meters above sea level, meant to be filled only in exceptional cases of catastrophic surge or failure of release and spillway mechanisms, as well as during renovation closures. In case of a flood, water is passed through with one or two holes of bottom release, or through both spillway spans. Biological water release is closed. Water management during drought is reduced to maintain a minimum level of impoundment through maintaining $Q_{\text {dys }}$ overflow from the reservoir equal to the $\mathrm{Q}$ inflow. If the flow is below its needs, a limitation of water supply for users downstream of the reservoir occurs. The period of drought is defined as a period when the following conditions occur together: the level of impoundment on the reservoir is less than or equal to the minimum level of impoundment, inflow to the reservoir is lower than the proper flow downstream $\left(0.10 \mathrm{~m}^{3} \cdot \mathrm{s}^{-1}\right)$, hydro-meteorological conditions do not indicate the occurrence of rainfall in the reservoir area which results in further deepening a state of low water (no flow increase in the Bóbr river). In contrast, during periods of ice cover (Figure 1b), it is advisable to maintain reservoir impoundment at normal levels, so the ice is not drawn into the spillway (dropping ice through spillways is forbidden). Dropping water in winter should be done by bottom release. Spillway trapdoor, niches, and gauge patches should be cleaned [Instrukcja 2007].

During the exploitation of reservoirs many problems appear, which may hinder or prevent its proper use. The Bukówka reservoir, just like other reservoirs, faces numerous problems. One of the main ones is a lack of constant hydrological and water quality monitoring at the tributaries and the reservoir itself, which would contribute to the proper use of water in the reservoir.

\section{Water quality}

Particularly important for the proper functioning of reservoirs, especially those containing drinking water, are water management issues in their basin areas. Dam reservoirs, due to their location at the lowest point of a basin are receivers of pollutants from the whole basin area, which make them very vulnerable to the processes occurring in a basin [Benndorf, Pütz 1987; Granlund et al. 2005; Skonieczek et al. 2013; Wegner et al. 1975]. A significant threat to the reservoirs is the process of eutrophication. Often the ability to use water in reservoirs depends on its quality, which is influenced, inter alia, by water and wastewater management in the basin of a reservoir [Wiatkowski, Paul 2009]. It was found that the sources of water pollution in the reservoirs' basins are point, dispersed and territorial sources [Koc et al. 2008]. The main causes of pollution of surface waters in the discussed area are: domestic waste waters containing organic compounds and nutrients channeled into watercourses without treatment, pollution from agricultural production, pol- 
lution flowing through surface watercourses from the Czech Republic, illegal landfills, area flows and linear pollution [Informacja 2011]. Studies showed that the main sources of the Bóbr river pollution are domestic and industrial waste water from urban centers and domestic waste water from rural community centers [Raport 2005]. In the basin area the villages of Paprotki and Miszkowice have sewage systems. Water is taken from intakes: Paprotki - drainage intake and Miszkowice - bank intake at the Złotna creek. Villages completely or partially void of sewage systems in the basin area are places like: Jarkowice. The villages of Opawa and Niedamirów were undergoing the process of sewage system construction [Informacja 2011]. During the study period in the basin area a fragmentary sewage system functioned, a small part of Miszkowice and Jarkowice had their own sewerage. Lubawka municipality has two waste water treatment plants which receive waste water from Bukówka, Miszkowice and Jarkowice. Waste waters from other villages of the municipality are transported to the treatment plant by a sanitation fleet or after domestic wastewater pretreatment channeled through the water or ground. During the study period the Lubawka municipality carried out or attempted to carry out tasks involving construction of a sanitary sewage system in villages: Jarkowice, Miszkowice, Opawa and Niedamirów.

At the Bukówka reservoir's basin there is no continuous monitoring of the water quality flowing into the tank. Periodic assessment of the water quality of the Bóbr river above the reservoir the Regional Inspectorate for Environmental Protection in Wroclaw carried out in 1993-2005. Table 1 shows the results of the quality of the water flowing into the Bukówka reservoir.

The Bóbr river water quality at the border showed considerable variability. An unsatisfacto- ry state of water was registered. Water flowing to Poland from the Czech Republic was characterized by unsatisfactory quality. A large number of faecal coliform bacteria, very high concentrations of phosphorus and increased color and phenolic index determined this classification. High pollution by phosphorus and nitrogen compounds in 2005 was much lower than in the previous year though. A significant annual fluctuation in the concentrations of nutrients for the period 19932005 in the water flowing to Polish was observed (Table 2) [Raport 2005]. As authors of the report concluded [2005], high concentrations of biogenic compounds pose a threat for the Bukówka dam reservoir eutrophication. Water quality assessment of the Bóbr river considering parameters characterizing the process of eutrophication, demonstrated exceeding annual average concentrations of phosphates and nitrates. The analysis of the least favorable indicators of water quality at the border (Table 1) showed that the Bóbr river water, due to its conductivity, may be classified into class I of water quality. In contrast, concentrations of nitrates, phosphates and $\mathrm{BOD}_{5}$ exceeded the water quality limits relating to surface water bodies in natural watercourses, such as a river, appropriate for class II [Rozporządzenie 2011].

Similar results, indicating high pollution of the Bóbr river flowing from the Czech Republic are presented Havranek [2011]. It concluded that the Bóbr river water flowing out from the Czech Republic should be included into the class $\mathrm{V}$ of water quality, due to the high content of total phosphorus.

On the other hand, our own water quality testing at the reservoir, conducted in 2006-2007, confirmed that from the point of view of eutrophication, hydrochemical conditions occurring in the Bukówka reservoir's basin are unfavorable for it, in terms of functions performed by the reservoir

Table 1. Average annual water quality indicators of the Bóbr river above the Bukówka reservoir at the border ( $\mathrm{km}$ 269.6) from the period between 1993 and 2005, from WIOŚ Wroclaw

\begin{tabular}{|c|c|c|}
\hline \multirow{3}{*}{ Indicator } & \multicolumn{2}{|c|}{ WIOS investigations (1993-2005) } \\
\hline & \multicolumn{2}{|c|}{ Bóbr river above the Bukówka reservoir, cross border } \\
\hline & min. (year) & max. (year) \\
\hline 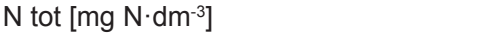 & $2.8(1997)$ & $>20(1994)$ \\
\hline Nitrates $\left[\mathrm{mg} \mathrm{NO}_{3}^{-} \cdot \mathrm{dm}^{-3}\right]$ & $12(1998)$ & >50 (1993, 1994, 1995, 1996, 2000, 2004) \\
\hline Phosphates [mg $\left.\mathrm{PO}_{4}{ }^{3-\cdot} \cdot \mathrm{dm}^{-3}\right]$ & $0.20(1997)$ & $>2.00(1993,1994,2000,2003,2004)$ \\
\hline $\mathrm{BOD}_{5}\left[\mathrm{mg} \mathrm{O}_{2} \cdot \mathrm{dm}^{-3}\right]$ & $5.0(1997,1999,2003)$ & $9.0(1995)$ \\
\hline Electrolytic conductivity $\left[\mu \mathrm{S} \cdot \mathrm{cm}^{-1}\right]$ & $200(1997,1998,1999)$ & $470(1994)$ \\
\hline The number of faecal coliform bacteria & 7000 (1997) & $400000(1993,1994)$ \\
\hline
\end{tabular}


[Wiatkowski et al. 2015]. In the waters flowing into the Bukówka tank concentrations of: nitrates ranged from $0.88 \mathrm{mg} \mathrm{NO}_{3}^{-\cdot} \mathrm{dm}^{-3}$ (Złotna and Bachorzyna) to $17.70 \mathrm{mg} \mathrm{NO}_{3}^{-} \cdot \mathrm{dm}^{-3}$ (Opawa); phos-

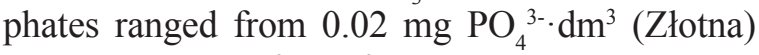
to $1.28 \mathrm{mg} \mathrm{PO}_{4}^{3-} \mathrm{dm}^{3}$ (Paprotki); ammonium ions ranged from $0.020 \mathrm{mg} \mathrm{NH}{ }_{4}^{+} \cdot \mathrm{dm}^{-3}$ (Złotna) to $0.640 \mathrm{mg} \mathrm{NH}_{4}^{+} \cdot \mathrm{dm}^{-3}$ (Opawa); nitrites ranged from $0.003 \mathrm{mg} \mathrm{NO}_{2}^{-\cdot} \mathrm{dm}^{-3}$ (Złotna) to $0.368 \mathrm{mg}$ $\mathrm{NO}_{2}^{-} \cdot \mathrm{dm}^{-3}$ (Ferns); $\mathrm{BOD}_{5}$ ranged from 1.0 to 11.00 $\mathrm{mg} \mathrm{O}_{2} \cdot \mathrm{dm}^{-3}$ (Opawa) and electrolytic conductivity ranged from 74 (Bachorzyna) to $714 \mu \mathrm{S} / \mathrm{cm}$ (Bóbr). The temperature of the water streams flowing into the reservoir during the analyzed period ranged from $2.1{ }^{\circ} \mathrm{C}$ (Bachorzyna and Opawa) to $22.5^{\circ} \mathrm{C}$ (Bachorzyna). The highest concentration of total suspended solids $-180 \mathrm{mg} \cdot \mathrm{dm}^{-3}$ - was observed in the waters flowing into the tank (Bachorzyna) Wiatkowski at al. 2015]. This is confirmed by tests of the water quality of the Bóbr river presented in [Operat 2007; Ocena 2007]. The tested waters from the Bukówka reservoir's basin are not vulnerable to pollution by nitrogen compounds from agricultural sources because concentrations of nitrate are lower than those recommended (50 mg $\mathrm{NO}_{3}^{-} \cdot \mathrm{dm}^{-3}$ ) [Rozporządzenie 2002].

In view of the fact that during the study period at the Bukówka reservoir a surface water intake protective zone "Bukówka" was established according to the permission OS-6210/8/97 for the planned Water Treatment Plant and water transfer to Wałbrzych [Operat 2007], the research should continue. At the time of the research only direct water intake for the citizens of the village located below the reservoir took place.

The basic water management problems at the Bukówka reservoir's basin include:

- The unsatisfactory state of water and waste water management in the catchment area (illegal channeling of sewage into the river Złotna and Paprotki ditch) (Figure 1),

- The unsatisfactory state of surface water quality in the basin of the reservoir (Figure 1),

- The poor condition of streams and drainage ditches (Figure 2),

- Improper arrangement of arable land and large slopes (which cause a rapid outflow of water and pollutants from the reservoir) (Figure 3a).

- A lack of water monitoring stations on the reservoir's tributaries (Bóbr, Opawa, Złotna, Bachorzyna, Paprotki). Currently, the gauge patch is installed downstream from the reservoir. This means that the reservoir does not have any hy- drological protection. Water monitoring devices should be installed in order to measure water levels on the reservoir's tributaries, even more so considering the fact that in the past such devices were present on Bóbr and Złotna.

Implementation of water management tasks should be assessed on the basis of its effectiveness, e.g. improvement of water quality, flood losses reduction etc. On the other hand, an identification of the water management problems, particularly in reservoirs' basin areas, is necessary to implement recovery measures.

\section{CONCLUSIONS}

Proper water management in the reservoir's basins should aim at improving water quality and seek to create conditions for its retention especially when it comes to reservoirs of water for human consumption. Eutrophication processes intensification in aquatic environments causes the decrease in water utility and aesthetic values of reservoirs. This may prevent a fulfillment of the reservoir's tasks.

Hydrochemical conditions in the Bukówka reservoir section are unfavorable for it. From the eutrophication perspective, water flowing into the reservoir is characterized by a significant content of nutrients. Levels of nitrates, phosphates and $\mathrm{BOD}_{5}$ have exceeded the water quality limits relating to surface water bodies in natural watercourses, such as a river, appropriate for class II.

In order to counteract the eutrophication it is necessary to lower the concentration of nutrients in the water inflow. One of the basic solutions is to organize proper water and wastewater management in the reservoir's basin.

Proposals for changes in water management in the reservoir's basin area, which start with the construction of sewage systems in towns located in the reservoir's basin, are (during the study period the measures were taken to provide sewage systems to the villages in the reservoir's basin area) the introduction of a protection zone around the reservoir limiting the use of land, a creation of monitoring stations on the tributaries of the reservoir and finally a restoration of clear flow in drainage ditches.

For a proper implementation of recovery actions it is necessary to identify water management problems, particularly at the drinking water reservoirs' basin areas. 
Studies carried out at the Bukówka reservoir provide valuable information on the state of waters supplying the reservoir. In order to obtain accurate information on the state of these hydrological and water quality monitoring should be continued.

\section{REFERENCES}

1. Balcerzak W. 2006. The protection of reservoir water against the eutrophication process. Polish J. of Environ. Stud. Vol. 15, No. 6, 837-844.

2. Benndorf J., Pütz K. 1987. Control of eutrophication of lakes and reservoirs by means of pre-dams I. Mode of operation and calculation of the nutrient elimination capacity. Wat. Res. 21, 829-838.

3. Czamara W., Czamara A., Wiatkowski M. 2008. The use of pre-dams with plant filters to improve water quality in storage reservoirs, Archives of Environ. Protection, vol. 34, 79-89.

4. Dyrektywa Rady 97/11/WE z dnia 3 marca 1997 r. zmieniająca dyrektywę 85/337/EWG w sprawie oceny wpływu wywieranego przez niektóre publiczne i prywatne przedsięwzięcia na środowisko.

5. Granlund K., Räike A., Ekholm P., Rankinen K., Rekolainen S. 2005. Assessment of water protection targets for agricultural nutrient loading in Finland. Journal of Hydrology 304, 251-260.

6. Havránek L., Kovář A., Zapletal T. 2011. Zpráva o hodnocení jakosti povrchových vod pro území ve správě Povodí Labe, státní podnik Odbor péče o vodní zdroje. Hradec Králové, wrzesień 2011, pp. 77.

7. Informacja o stanie środowiska w powiecie kamiennogórskim, Kamienna Góra, maj 2011 r. pp. 27.

8. Instrukcja gospodarowania wodą dla zbiornika wodnego Bukówka. Powiat kamiennogórski, woj. dolnośląskie, Integrated Engineering Sp. z o.o. na zlecenie RZGW Wrocławiu, Raszyn 2007, pp. 22.

9. Kanownik W., Kowalik T., Bogdał A., Ostrowski K., Rajda W. Jakość i walory użytkowe wód odpływających ze zlewni zbiorników małej retencji planowanych w rejonie Krakowa. Wyd. UR w Krakowie, Kraków 2011, pp. 110.

10. Koc J., Duda M., Tucholski S. 2008. Znaczenie zbiornika retencyjnego dla ochrony jeziora przed spływami fosforu ze zlewni rolniczej. Acta Sci. Pol., Formatio Circumiectus 7 (1), 13-24.

11. Konwencja o ochronie i użytkowaniu cieków transgranicznych i jezior międzynarodowych, Sporządzona w Helsinkach, dnia 17 marca 1992 roku, Narody Zjednoczone 1992.

12. Ocena stanu jakości rzek województwa dolnośląskiego w 2007 roku. Wojewódzki Inspe- ktorat Ochrony Środowiska We Wrocławiu, pp. 54.

13. Operat wodnoprawny dla zbiornika wodnego Bukówka. Powiat kamiennogórski, woj. dolnośląskie, Integrated Engineering Sp. z o.o. na zlecenie RZGW we Wrocławiu, Raszyn 2007, pp. 22.

14. Pütz, K., Benndorf J. 1981. Die zielgerichtete Wassergütebewirtschaftung von Talsperren und Speichern - Information zum Fachbereichsstandard TGL 27885/03, Acta hydrochim. et hydrobiol., 9, 25-36.

15. Pütz K., Paul L. 2008. Suspended matter elimination in a pre-dam with discharge dependent storage level regulation. Limnologica, 38, 388-399.

16. Przybyła Cz., Kozdrój P., Sojka M. Ocena Jakości wód w lateralnych zbiornikach Jutrosin i Pakosław w pierwszych latach funkcjonowania. Inżynieria Ekologiczna, Vol. 39, 2014, 123-135.

17. Raport o stanie środowiska województwa dolnośląskiego w 2005 r. WIOŚ, Wrocław 2005.

18. Skonieczek P., Koc J., Duda M. 2013. Wpływ zbiorników retencyjnych w ochronie jezior przed zanieczyszczeniami spływającymi z obszarów wiejskich. DOI: 10.2429/Proc.2013.7(1)033.

19. Rozporządzenie Ministra Środowiska z 23 grudnia 2002 roku w sprawie kryteriów wyznaczania wód wrażliwych na zanieczyszczenie związkami azotu ze źródeł rolniczych. Dz. U. Nr 241, poz. 2093.

20. Rozporządzenie Ministra Środowiska z 9 listopada 2011 roku w sprawie sposobu klasyfikacji stanu jednolitych części wód powierzchniowych oraz środowiskowych norm jakości dla substancji priorytetowych. Dz. U. Nr 257, poz. 1545.

21. Wegener U., Dörter K., Beuschold E. 1975. Der Einfluss der landwirtschaftlichen Nutzung von Talsperreneinzugsgebieten auf den Nährstoffeintrag in Trinkwassertalsperren. Acta hydrochim. hydrobiol. 13, pp. 553-561.

22. Wiatkowski M., Paul L. 2009. Surface water quality assessment in the Troja river catchment in the context of Włodzienin reservoir construction. Polish J. of Environ. Stud., Vol. 18, No. 5, 923-929.

23. Wiatkowski M., Rosik-Dulewska Cz., Wiatkowska B. 2010. Charakterystyka stanu użytkowania małego zbiornika zaporowego Nowaki na Korzkwi. Rocz Ochr Środow., T. 12, 351-364.

24. Wiatkowski M. 2011. Influence of Słup dam reservoir on flow and quality of water in the Nysa Szalona river. Polish J. of Environ. Stud. Vol. 20, No. 2, 467-476.

25. Wiatkowski M., Rosik-Dulewska Cz., Kasperek R. 2015. Analysis of the impurity supply to Bukówka reservoir from the transboundary Bóbr river basin. Roczn. Ochr. Środow. (Ann. Set The Environ. Prot.), in print. 